\title{
Politeness in Language by the Politicians in the Discourse of Jakarta Election
}

\author{
Agustina \\ Faculty of Language and Arts \\ Padang State University, Indonesia \\ tienagustina17@gmail.com
}

\begin{abstract}
Of the 101 regions conducting the election of regional heads in Indonesia in the first quarter of 2017, apparently Jakarto election was is the most very time-consuming and attracted the most attention of not only the people Jakarta, but also throughout Indonesia in general. The election was not only fully loaded with political contents, but also its implications on the use of language as a polical means. Based on the data analysis in this research, it was found out that the language used by politicians in the discourse of Jakarta election was aimed at seizuring power. The result was violation of the principles of politeness in language verbal abusing, censuring and even for waging hatred, conflict, and SARA sentiment. Such phenomena are not only exhibited either in print media or electronic but also through social media. Based on above reasons, this study becomes important to conduct because in the discourse of Jakarta election, language function as tool of cooperation in social interaction is no longer bringing the clarity of its function so that causing social unrest as well as security instability in the midst of society. Moreover, this article is part of the result of the research entitled: "Verbal violence in Political Discourse during Jakarta Election: A study of Socio-Pragmatic”.
\end{abstract}

Keywords- speech acts, politeness, politician, Jakarta Election.

\section{A. Background of Problem}

\section{INTRODUCTION}

Functionally, language as a tool for communication plays a very important role to build culture and civilization of a nation. It is because language as a social instrument will lead the user community towards possessing identity and character based on the built language values. Therefore, the better the language used, the easier the intention and the message implemented. On the contrary, the more the unconverted language used, the more wild the interpretation raised. In the pragmatic study, in addition to the component of the speech actor, content and message conveyed is speech form factor as well as way of its disclosure being the determinant of the success of a communication. Furhtermore, the use of improper language resulting the wrong perception so that becoming a major constraint in the communiation process. If the communication constraint is not managed in such manner, it will create dispute, hostility and conflict for the community as its user.

This phenomenon also appeared in recent Jakarta election. Based on the results of the research, it was revealed that some of the news packaged in certain forms and styles of disclosure used by political elites, journalists, and community supporters of the governor candidate, tends to be abusive, berate, spread the hard-to-answer issues, even tends to distort the facts so that potentially cause unrest in society. Based on the above statement, this research has an important place related to the stability and security of the country. Apparently, the use of language in political discourse in the mass media is not longer bringing the clarity of meaning because it has been manipulated for the interests of political elites and certain groups, resulting in language manipulation and deviation of language functions as a tool of cooperation. This discussion attempts to capture and to map the politeness of language from the community supporters of governor candidates which is voicing the discourse of Jakarta Election in mass media.

\section{B. Problems and Objectives}

The problems proposed in the study, namely: "How is the language politeness from the politician in the discourse of the Jakarta Election?". To answer the problem, the discussion section will contain five specific objectives, such as to define and describe: (1) the types of speech acts used, (2) the selected expression forms, (3) the speech act strategies applied, (4) compliance or violation of the principles of politeness, and (5) the position/scale of politeness used by politician in the discourse of the Jakarta Election.

\section{A. Pragmatics}

\section{THEORETICAL REVIEW}

Pragmatics is used as the main theory in this discussion along with the concept of speech acts and politeness. Pragmatics is a study of languages that study the relations of language with its context (Levinson, 1983, p. 9); discussion of meaning to speech situations (Leech, 1993, p.8); a study of the ability of language-user to link and to harmonize sentences with its context (Agustina, 1995, p. 14 ); and the study of how the language is used in communication (Wijana, 1996, p. 1). It can be concluded that pragmatics examines the rules of the use of language form and meaning related to the intentions of the speaker under the context 
and function of the speech. Thus, in the discussion of speech discourse in Jakarta Election, the context of political development around Jakarta Election becomes very crucial in tracking the function and meaning of the written expression.

\section{B. Speech Acts}

Speech Act is a statement that contains action under the speech (Sherry HQ, et al., 2012, p. 62). The scale of politeness in a conversation can be traced to the type of speech acts used, the chosen form of expression, and the speech strategy. Based on the theory of Searle (1976, p. 1-2), there are five types of speech acts that determine politeness. (1) Assertive speech acts, including the speakers to the truth of what he says, such as: stating, reporting, demonstrating, and mentioning. This type has a higher level of vulnerability related to the truth of a statement, the politeness tend to be neutral because it belongs to the category of cooperation, unless it is being boasted. (2) Directive speech act, directing the listener to do what the speaker says, in the form of ordering, pleading, suggesting, asking, patronizing, and advising; which serves a pleasant function, except to instruct and to patronize that potentially to threat the face so that it can be softened with imperative of allowing, inviting, and banning (Rahadi, 2000, p.56). (3) Expressive speech acts, this type aims to evaluate a situation, such as: praising, criticizing, thanking, and complaining, but criticizing and the like are competitive and tend to threaten the face of listener. (4) Commissive speech acts, aims to bind its speakers to carry out what is mentioned, such as pledging, swearing, forcing, condeming, and threatening; has an unpleasant function and very potential to threaten the face of listener. (5) Declaration speech acts, aims to creating new status or circumstances, such as: deciding, withdrawing, allowing, prohibiting, influencing, and forgiving, it is practiced by authorized speakers.

The use of the types of speech acts above along with its function in speaking. Leech (1993, p. 162-263) classifies the function of illocution on the basis of its relation to social objectives of maintaining polite and respectful manners, in four functions. (1) The competitive function, the illocutionary goal competes with the social goal. This negative politeness aims to reduce the implied disharmony in competition, between what is to be achieved and what is demanded in politeness. (2) Convivial function, the illocutionary goal coincides with the social goal, which is more positive-shaped politeness and aims to find opportunities to be polite. (3) Collaborative function, the illocutionary goal is indifferent to the social goal. (4) Conflictive function, the illocutionary goal conflicts with the social goal, where there is no politeness at all because it aims to generate anger, such as threatening, accusing, cursing, and offending.

The politeness of a speaker is also determined from the form of expression, such as diction or figure of speech which he/she chooses as medium. Of the many language styles and figures of speech associated the satire language styles are more closely related than others. There are four types of figure of speech that are included in the satire language style: (1) sarcasm, the rudest, harshest, sarcastic, mocking, insulting, derisive without parable so it hurts for those who receive it; (2) cynicism, one of the rudest figures of speech; (3) irony, the most subtle kind of satire, the listener usually does not feel it directly because it uses the opposite expression; and (4) alusio, this one generally uses the familiar proverbs/phrases in the process (Keraf, 2010, p. 143145).

The application of politeness strategy aims to reduce the disappointment of the listener over the actions performed by the speaker. In this study, the politeness strategy refers to the notion of Brown and Levinson (1987, p. 103), which is (1) bald onrecord, (2) positive politeness, (3) negative politeness, (4), vague, and (5) off-record. Bald on-record strategy according to BlumKulka is a direct speech so this strategy has full potential to threaten the face of the addressee.

\section{Politeness}

In the pragmatic study, politeness is a procedure or habit in the form of social behavior that is determined and agreed upon by a particular society. Thus, politeness is a system of interpersonal relations designed to help interaction by minimizing the potential for conflict and confrontation (Lakoff in Syahrul, 2008, p. 15); property associated with the speech where the speaker does not transcend the right of the hearer in fulfilling his/her obligations in a speech event (Frasser, in Chaer, 2010, p. 47). So, politeness is a universal phenomenon because in communicating, the norms apply to the use of any language in the world. But, in reality politeness is a complex phenomenon. Politeness is changing due to the influence of dynamic interaction between language, culture, and social values (Yaolong, 2008, p. 27).

Thus, Leech (1993, p. 206-207) explains that politeness is an attempt to create mutual trust and the presence of rude opinions to be as small as possible by obeying the six principles of politeness as follows. (a) Tact maxim: minimize the expression of beliefs which imply cost to other; maximize the expression of beliefs which imply benefit to other (b) Generosity maxim: minimize the expression of beliefs that express or imply benefit to self; maximize the expression of beliefs that express or imply cost to self. (c) Praise maxim: minimize the expression of beliefs which express dispraise of other; maximize the expression of beliefs which express approval of other. (d) Modesty maxim: minimize the expression of praise of self; maximize the expression of dispraise of self. (e) Agreement maxim: minimize the expression of disagreement between self and other; maximize the expression of agreement between self and other. (f) Sympathy maxim: minimize antipathy between self and other; maximize sympathy between the self and other

Functionally, politeness in relation to avoidance of a conflict, with the concept of face referring to "self-image", is something that is emotionally invested (which can be treated, lost or abandoned) and which must be consistently present in the interaction 
(Brown and Levison, 1987, p. 62); which manifests into a negative face and positive face (Yule, 2006, p. 111-112). According to Brown and Levinson (1987, p. 65-67) the concept of the face is universal and tends to relate to unpleasant actions or threatening a face.

In speech should be based on a decision: (1) If the speaker wants to keep the face of the hearer, then try to speak politely. (2) If the speaker wants to violate the positive face of the listener (for his acceptance and acknowledged good image), then the speaker uses a positive politeness strategy. (3) If the speaker wants to violate the negative face of the listener (violates the desire of the speaker not to be disturbed or undermined his/her rights), then the speaker uses a negative politeness strategy (Brown and Levinson (1987, p. 42).

In communicating, the role of the speaker is not only to convey information but also to maintain and preserve the social relations between speakers and listeners (Gunarwan, 1992, p. 184). For this reason, Grice redefined that assumption as "to select an utterance that does not underestimate the status of the listener or the utterance causes the lowest risk of losing face", with details (1) do not treat the listener as a party that is subject to the speaker, or the party affected by the social cost, physical cost, psychological cost, or limits their freedom; (2) do not say unfavorable things about other people or stuffs related to the listener; and (3) do not express the pleasure over the misfortune of listener (in Pranowo, 2008, p. 6).

In line with that, to determine the level of politeness, we can use politeness scales proposed by Brown and Levinson (1987, p. 65-68) based on Face Threatening Acts (FTA) with two parameters. (1) Negative threatening actions, such as command, threat, warning, challenge, hatred, anger, etc. (2) Positive threatening action, in the form of criticism, humiliation, accusation, humiliation, etc. along with provocative utterance which can divide races, religions, and unsuitable representation. Besides, the researchers also used the 'scale of indirectness' of Blum-Kulka (1985, p. 5-6) with the formula "The more direct you deliver the speech, the less polite your utterance; but the more indirect you deliver the speech, the more polite your utterance."

\section{METHOD}

The methodology applied in this discussion is the qualitative research as the event of Jakarta election is the natural object (Moleong, 2010, p. 11); by use of descriptive method that prioritizes the depth of appreciation to interaction of the among concepts in which being studied empirically (Semi, 1993, p. 24). Analyzing data through content analysis method is done to reveal, understand, and capture messages in data, and make conclusions obtained through identification and interpretation of data (Endaswara, 2011, p. 160).

The data of this research are sentences containing political expressions by politicians in line with in the discourse of the Jakarta Election, which are found in print mass media of Rakyat Merdeka Newspaper in the column of 'tweetpolitic' and in electronic medias of 'Liputan6.com, 'Kompas.com', and 'Detik.com which were downloaded randomly in a period of January April 2017, during the campaign until the winner's determination. The selection of this research object, in terms of both content and data sources, is based on the following considerations: (1) the focus of research, which is the type, form of expression, the spoken strategy used, and the principle of politeness that is obeyed or violated; (2) the target of research, namely the elections of DKI as one of the barometer of political situation in Indonesia; (3) the type and value of literacy/discourse chosen, that is influencing the public interest because social media has been classified into public speaking; (4) the level of user community/consumer discourse, ie representing aspects of education, age, and social status of the general public (Agustina, 2017, p. 240).

\section{A. Findings}

\section{FINDING AND DISCUSSION}

Based on the results of this study, the researcher obtained the recapitulation of data classification result for the use of the politeness element and the politeness level of the politicians in the political discourse of the Jakarta Election can be presented in the table 1 below.

Table 1. Recapitulation of Research Data Analysis

\begin{tabular}{|c|c|c|c|c|c|c|c|c|c|}
\hline \multicolumn{10}{|c|}{ Element of Politeness } \\
\hline $\begin{array}{c}\text { Type of } \\
\text { Illocution }\end{array}$ & Total & $\begin{array}{c}\text { Diction } \\
\text { and } \\
\text { Figure of } \\
\text { Speech }\end{array}$ & Total & $\begin{array}{c}\text { Politeness } \\
\text { Strategy }\end{array}$ & Total & $\begin{array}{l}\text { Politeness } \\
\text { Principle }\end{array}$ & Obey & Violate & Total \\
\hline Expressive & 34 & Cynicism & 35 & Bald on-record & 34 & Sympathy & 3 & 18 & 21 \\
\hline Directive & 28 & Carcasm & 27 & Negative politeness & 16 & Tact & 5 & 15 & 20 \\
\hline Assertive & 20 & Irony & 21 & Positive politeness & 15 & Agreement & 3 & 13 & 16 \\
\hline Commisive & 6 & Alusio & 5 & Off-record & 23 & Approbation & 1 & 12 & 13 \\
\hline & & & & - & & Modesty & 1 & 11 & 12 \\
\hline & & & & - & & Generous & 1 & 5 & 6 \\
\hline Total & 88 & Total & 88 & Total & 88 & Total 88 & 14 & 74 & 88 \\
\hline
\end{tabular}




\section{The Use Types of Speech Acts}

Based on the data classification, there are four types of speech acts used by politicians in expressing their opinions. The most dominant of the speech acts used is expressive, which aims to evaluate what is said in line with the Jakarta election, it is expressed in five ways: criticizing (1), mocking (2), regreting (3), (4), deprecating (5) accusing (5), and censuring (6).

a. DEBAT itu adu program terbaik bukan adu omong kosong. (FR, RM:3/4/17)

'DEBATE is the show of the best programs, not a mutual nonsense'.

b. Tugas pengamat itu berikan pandangan secara objektif \& ilmiah, kasih data apa adanya... Kalau selalu ditengah itu namanya resleting celana (YW, RM:13/3/17)

The observer's task is to provide a view objectively, scientifically, give the data as it is....

'If always in the middle position naming zipper of trousers'.

c. "Kalau terdakwa tidak sampaikan surat Al Maidah, tidak masalah. Pilgub DKI ini. Tak ada masalah kalau terdakwa tak sebut (Al Maidah 51) di Pulau Seribu," ucap dia (MA, L6c:21/2/17).

'If the defendant hadn't delivered Al Maidah's letter, it would have been no problem on this Jakarta election. It would have been no problem if the defendant hadn't mentioned ( Al Maidah 51) in Pulau Seribu'.

d. Sejak awal PAN sudah bersikap tidak akan mendukung Ahok karena dari karakter dan etika tidak cocok sama PAN," ucap Y... (Y, L6c:18/2/17).

'From the beginning PAN's attitude would not support Ahok because of seeing from character and ethics did not match with PAN", said Y...'

e. "Sudah sah, itu merupakan bagian dari strategi kampanye (Ahok-Djarot). Kami sudah siapkan tim hukum .... " kata S....(SU, L6c:24/3/17)

'It is legitimate, it is part of the campaign strategy (Ahok-Djarot)"...said S We have prepared the legal team'.

f. Dari Senayan sampai Istana, berjejer Tukang Orba. Sambung menyambung menjadi satu, itulah kemunafikan. (RG, RM:16/03/17)

'From Senayan to the Palace, those are New Order's actors. If connected together, that is hypocrisy'.

The choice of expressive speech acts by criticizing, mocking, regretting, censuring, and accusing indicates that the politician is not trying to speak more polite so that his behavior creates a 'higher' level of face vulnerability because the goal of this speech is competitive. In the most of their speeches, the purpose of the illocution is to compete with the social objective so that politeness are negative and its purpose is to reduce disharmony.

The next dominant speech acts used by politicians are directive, a speech that asks the addressee to do something, which is delivered in the form of persuasion (7), appealing (8), invoking (9) advising (10), and demanding (11).

a. Jagad politik sudah mulai ramai. Tidak apa-apa saling silang pendapat, asal jangan berkutat di kubangan fitnah. Yuk, kita bangun negeri kita. (M, RM:11/1/17) 'The political universe is starting to rumble. It does not matter if it's different, as long do not get trapped in a slander pool. Let us build our country together'.

b. "Saya berharap format debat bisa elaborate sampai detail sehingga masing-masing pasangan tidak sibuk menyerang karakter orang," tegas $\mathrm{Dj} . .$. (DSH, RM:30/3/17).

c. 'I hope the format of the debate can be elaborated into details so that the respective pairs of the candidate are not busy with attacking the character of people". Dj. Asserted'.

d. "Bapak-bapak politikus santun yang saya hormati, tolonglah berperilaku sebagai negarawan. Pilkada DKI sudah selesai. Sekarang waktunya fokus membangun Jakarta yang lebih baik," ujar .... (C, Dc:28/4/17). 'The honorable politicians whom I respect, please behave as statesman until Jakarta election is over. It is now the time to focus on building a better Jakarta'. Jangan habisi lawan-lawanmu sehingga jadi ampas. Hadapi dengan fair \& perlakukan mereka dengan respek... (BS, RM:27/1/17) 'Do not destroy your opponent until it becomes dregs. Deal with the fair \& treat them with respect...'.

e. Wakil Ketua ACTA mengatakan pihaknya tetap menginginkan pasangan calon nomor dua Basuki Tjahaja Purnama (Ahok- Djarot) Saiful Hidayat didiskualifikasi dari Pilkada DKI Jakarta, terkait politik uang bersifat TSM. (AL, Kc:28/4/17). 'Vice Chairman of ACTA stated that his side still wants pairs of candidate of number two is Basuki Tjahaja Purnama (Ahok-Djarot) Saiful Hidayat being disqualified from Jakarta election eventhough they have already lost in election, related to money politics in the form of TSM'.

The form of the utterances delivery begins with softening illocution power in the form of persuasion, appealing, and invoking until at demanding and advising in the theory Leech (1993, p. 162-1630) is actually having less potential to threat the face of speech partner because it is convivial as the purpose of illocution in line with social goals. However, due to the choice of its diction being conveyed by way of insinuation, it still has potential to threaten the face of the intended party.

Another type of speech acts used by is assertive, which binds the speaker to the truth of his statement. This type is stated by the politicians in three ways, viz., showing by example (12), expressing opinions (13), convincing (14), and asking questions (15). 
a. Ingin tahu seseorang korup/tidak, beri dia kekuasaan. Ingin tahu seseorang cendekiawan/anggota gerombolan, beri dia PILKADA. (S, RM:20/2/17) 'Want to know someone is corrupt or not, give him a power. Want to know someone a scholar or member of a gangster, offer him an election'

b. Saya berhak menentukan siapa yang saya anggap pantas menjadi ulama/imam bagi diri saya sendiri, dan saya pilih sosok yang tidak menghujat ( $\mathrm{Dj}, \mathrm{RM}: 30 / 1 / 17$ ). 'I have the right to decide whom I consider to become a right religious leader/priest for myself, and I vote for a non-blasphemous person'.

c. Fitnah, kebohongan oleh manusia-manusia kerdil mulai ditebar lagi jelang putaran 2. Pemimpin yang menang dengan memfitnah lawannya tak kan bertahan lama (AT, RM:20/2/17). 'Calumny, lies done by dwarfs began spreading again ahead of the second round. Leaders who win by slandering their opponents will not last longer'.

d. Benarkah karkater seseorang cenderung sama dengan karakter para politisi yang didukungnya? (DL, RM:6/3/17) 'Is it true that someone's character tends to be the same as the politician's character he supports?'.

As in the assertive speech acts, the speaker is bound to the truth of what he says, so from the point of illocution politeness tends to be neutral unless the truth of the statement is doubtful (Leech, 1993, p. 164). Nevertheless, the context of this research is relating to the power constellation, then the choice of words tends to mean blasphemy and reproachful conveyed by way of insinuation so that it still has potential to threaten the persons whom being insinuated.

The kind of speech act at least used by the politicians is commissive Although commissive speech acts are generally less competitive, but the use of a very negative diction such, cursing (16), challenging (17), threatening (18), and it binds the speaker to commit his intention, so it seems to be less polite because of being conveyed before the public.

a. Kaya harta, jabatan mulia, masih terima suap. Tak bisa berkata apa-apa menanggapinya, selain kata SERAKAH. (MP, RM:27/1/17). 'The wealthy, noble position still receive a bribe. Unable to say anything to respond it, other than the word GREEDY'.

b. Memilih itu hak azazi. Kalau ada yang ngelarang berarti dia bukan warga bhineka tunggal ika. Saya nggak takut, dan saya ikhlas kalau meninggal tidak dishalati, kata Dj. (DF, RM:15/4/17). 'To vote for is a human right. If any body prohibits means that he/she is not a citizen of unity in diversity. I am not scared, and I am sincere if the ritual prayers of my corpse is not perfomed. Said Dj.'

c. Saya katakan, jangan memanfaatkan peluang (kekalahan Ahok-Djarot) untuk masuknya praktik-praktik buruk masa lampau, ujar Dj. ..(DSH, Kc:29/4/17). 'I say, please not to take advantage of the opportunities (defeat of Ahok-Djarot) for the entry of bad practices on the past, said Dj'.

\section{The Use of Diction and Figure of Speech}

Based on the research results, the politicians having in their opinions and comments, generally use dictions and utterance that tend to lead to a verbal violence. However, in order that they still look impressed polite, they are dominant in using satire and irony because it is already in the public speaking sphere. The facts can be seen in the following data that the politicians only uses satirical language styles through sarcasm (19), cynicism (20), irony, (21), alusio (22).

a. IBLIS juga bisa beri kekuasaan. Tapi bedanya kekuasaan yang datang dari TUHAN membawa keberkahan sedang yang dari IBLIS membawa kerusakan. (AM, RM:6/4/17). 'SATAN can be a ruler. However, the difference of power coming from the LORD brings a blessing, while SATAN leads to a total destruction'.

b. Pilkada DKI membuktikan sisi gelap agama. Betapa jahatnya agama yang dipolitisasi. Betapa jahatnya orangorang beragama. (@, RM:14/3/17). 'The Jakarta Election shows the dark side of a religion. How wicked if religious teachings have been politicized. How wicked these people are..'

c. Islam nggak sangar kayak begitu. Islam itu sejuk, damai. Islam itu merangkul, bukan mukul," tutup Dj.... (DSH, Dc:20/3/17). 'Islam is not such spooky. Islam is cool and peaceful. "Islam is embracing, not hitting" closed'.

d. Meratakan gunung lebih mudah daripada memperbaiki watak orang (pepatah Tiongkok) (NK, RM:3/2/17). 'Levelling mountain is more easier than improving the people's character (Chinese proverb)'.

The delivery of opinions by the politicians through satirical sarcasm and cynicism directly, openly and massively followed by rough, bitter, and foul words. It occupies a 'very high' possibility to threaten the face of the recipients.

Uses other figure of speeches like irony and alusio even though it is not too dominant, however, the selected diction is still potential for 'threatening a positive face.' Therefore, the choice of diction/utterance used indicates that the supporting community of governor candidates of Jakarta disregarded Grice formulation (dalam Pronowo, 2000, p. 362): "please choose an utterance that does not underestimate the status of recipient or to create an expression that has the smallest possibility to lead to a facelosing." 


\section{The Application of Speech Strategy}

The politicians use the four types of strategies chosen in expressing their opinions about the Jakarta election: the bald onrecord strategy (23) negative politeness (24) and positive politeness strategy (25), vague strategy (26).

a. Memilih pemimpin kafir itu "sesat”, tetapi memilih pemimpin yang suka "meng-kafirkan" orang, itu juga sesat... Ya Allah mohon petunjukMu. (LE, RM:20/2/17). 'Choosing a non-Islamic leader is 'mis-guided,' but choosing a leader who likes to 'arraign' people, is equally misguided. Oh God, I beg for your guidance'.

b. Menuju Pilkada DKI 15 Feb 2017, fitnah, penjegalan, dan pembunuhan karakter makin tak beretika. Saudarasaudaraku, sadarlah kita semua sebangsa. (MR, RM:31/1/17) 'Calumny, smear-campaign, and character assassination in the elections of DKI 2017 become increasingly uncivilized. My brothers, be aware, we are all one nation'.

c. "Tentunya kita harus selalu mengingatkan kepada masing-masing kita bahwa kita sekarang bukan sedang mencari pemimpin agama, tetapi kita sedang mencari pemimpin pemerintahan," ujarnya (MSP, Dc:31/3/17). "Off course we have to always remind each of us that right now we are not looking for a religion leader, but looking for a government leader," he said'.

d. Apabila masing-masing "menghitamkan" yang lain, siapa yang kemudian harus terlihat "putih"? (MB, RM:30/1/17). 'When each other "blackening" another, who should look "white"?

Very phenomenal fact is on the one side, the dominant politicians using bald on-record strategy which is very high to threaten the face of recipient, but on the other hand they use a vague strategy that is less threatening face. In the political context, it seems that the politicians with high determination and ambition would do everything possible for justification of the nominated both candidates or justification of the opinion about the situation being less condusive at that time, however, they still try to keep their professional image by softening illocusion power using the vague strategy so as not to overturn the intended face. Nevertheless, judging from the overall data obtained, evidently the use of the strategy which is highly threatening the face of the recipient (bald on-record strategy and negative politeness) is more dominant than using the strategy that is less potentially threatening the face (positive politeness and vague strategy). Thus, the use of strategies spoken by politicians is in a 'somewhat high' position threatening the intended face.

From 'scale of indirectness' (Blum Kulka,1985, p. 5-6), this bald on-record strategy belongs to 'direct speech', whereas based on the 'scale of vulnerability' (Brown dan Levinson, 1987, p. 65-68), this strategy is very high to threaten the face of recipient. Although three other strategies such as negative politeness, positive politeness, and off-record, includes into 'indirect speech', they are still categorized as threatening face due to negative word choices.

\section{Implementation of Politeness Principle}

To create a polite speech, the experts offer seven principles of politeness that speakers should choose according to the needs and context of speech. In this study, the violation of the principle of politeness is greater than obeying it. From the analyzed data at point 1-3 above, the politicians generally do not adhere to the principles of politeness as stated by Leech (1993, p. 206-207). Following is the example of violation beginning from the most dominant to the minimal one is found in the data are among others.

Clear violation of tact principle happens in the data (23), (24) through maximalization of social and psychological harm to the other politician as being delivered in the form of forcing and reproaching; and also the violations of sympathy principle appear in the data (12), (20), in this utterance, there is the maximization of the antipathy towards the addressee with through blatant condemnation. In the data (5), (6) the speaker violates agreement principle through an exaggerated view by him/herself. Then, violation of approbation principle in the data (2) and (4), the politician is too exaggerated to express his opinion and judgment so that from the choice of words implicitly has the meaning of insulting and reproaching, even though he believes in what he says is violation of modesty principle in data (17). There is too much boasting of own opinion for being desperately supportive so that it may seem anomalous to publish, even if it is the privilege of the person concerned; while the violation of the generosity principle in the data (11) for the sake of winning, the excessive provocation occurred to hit the opponent with a one-sided prosecution, although it is believed that the claims have not been through the judicial process so it is not yet eligible for publication.

Being compared with the following data which adhering to the principle of politeness, i.e. sympathy principle (27), tact principle (28), agreement principle (29), approbation principle (30), modesty principle (31), and generosity principle (32).

a. Semoga Allah memberikan hidayah pada para pemimpin negeri ini agar segera menyadari jangan melebarkan perbedaan, tapi menyatukan, menyejukkan (EG, RM:4/2/17). 'May Allah give guidance to the leaders of this country to be immediately aware of not widening the differences, but uniting and soothing'.

b. Kepala yang penuh pengetahuan tidak akan lebih hebat daripada hati yang penuh iman (MR, RM:14/4/17). 'A knowledgeable head will not be greater than a faithful heart'. 
c. Radikalisasi agama bisa berkembang karena dua hal. Pertama, fahamnya memang fundamentalis, dan kedua agama diperalat untuk kepentingan politik (RI, RM:15/4/17). 'Religious radicalism can develop in two ways. First, its ideology itself is fundamental, and second, both religions are used for political purposes'.

d. Menghadapi berbagai ujaran kebencian, fitnahan, saya bilang sabar. Hadapi mereka dengan senyum yang tulus. Doakan, karena mereka Saudara kita (DjSH, RM:15/4/17). 'Facing various hate speech, slander, I say please be patient. Face them with a sincere smile. Pray for them because they are our brothers'.

e. "Menurut A..., sebenarnya semua orang bisa jadi gubernur asalkan tidak punya kepentingan, karena contohnya sudah ada", tutupnya (BCP, Dc:27/4/17). 'According to A ..., actually everyone can be a governor as long as having no any interest, it is because the example already exists", he concluded'.

f. Saya rasa kita sama-sama menentang jika terjadi pengusiran orang beribadah. Jangan terulang lagi. Namun harus diakui juga bahwa kondisi berbangsa kita kritis saat ini (FR, RM:15/4/17). 'I think we are altogether opposed to the expulsion of worshipers. Please do not repeat it again. However, it must also be recognized that our nation is under critical condition at this time'.

\section{B. Discussion}

Based on the classification and the analysis of data, the study of the politician politeness in the discourse of Jakarta election being discussed from four elements of politeness as the object of study in this research.

The choice of expressive speech acts aims at evaluation, meanwhile assertive acts aims to justify of what is mentioned, according to Leech (1993, p. 164-165) if it is to select a neutral and positive form, the type of speech acts is the right one in communication. Moreover, the politician as a public figure and the governing party is required to perform the convivial function in order that the speech is in line with social goals as well as collaborative functions to be more deliberative on the problems encountered. However, in this research data, the politician is rather dominant to choose a negative way so that his speech switch function to be competitive with social goal to reduce implied harmony. Then, the use of directive and commissive speech acts will affect the action competitive and conflictive functions with the social goal, so the speech is indeed potential for face threatening acts with a 'rather high' level because of the parameters proposed by Brown and Levinson (1987, p. 65-67) conveyed through sharp criticism, condemnation, threat, accusation, and insunation so that to be patronizing and disgraceful.

The facts are proven in the research data through the dominant expression in the form of cynicism, irony, and sarcasm, and the dominant application of 'bald on record' strategy rather than other strategies, then the politeness indicators in the form of 'the scale of indirectness' as proposed by Blum-Kulka (1985, p. 14): 'The more direct the utterance is expressed, the lesser polite the expression' is evident in this study. Based on observations on the context of the expression in this research data, politicians have tried to speak more polite (proven by dominant use of cynicism), however the diction was ineffective and insensitive so it still has great potential to disrupt the intended party. In this case, the scale of politeness with Grice's scale of face-threatening (in Pranowo, 2008, p. 362) "Choose an expression that does not underestimate the listener ..." is less calculated by politicians so it has potential to threaten the positive and negative face and produced 'less polite' speech. Another determinant factor that supports the findings of this research is politician's speeches as the target of this research is delivered in the mass media; it means it has become the realm of public speaking.

The impact of the phenomenon is still feared by many., The same thing is also voiced by Inayah Wahid, that the attitude of political elites who easily convey verbal violence is potentially thickening prejudice in the society in general, it is therefore the political elite being expected to be self-conscious to prioritize the nation's social cohesion rather than to achieve short-term political gain with political capitalization through allegations to others or mutual accusations among political elites; Indro Nugroho (Atmajawa Political Psychologist) is concerned that a political elite statement containing verbal violence in the form of a strong no-base accusation will lead to social conflict in the society; thereafter Prof. Azyumardi Azra (State Islamic University, Jakarta) appeals to "political elites in order to stop verbal abuse statements that have no evidence as to trigger and strengthen the escalation of hatred in society as well as to create (Baranews.co, 2017, 5/8).

The result of the research, in fact it is still relevant to the research conducted by Rahyono, et.al (2005:54) that is the main characteristic of information delivery in the New Order Post media, was " straightforward news followed by a hyperbolic and abusive language, such as censure, complaints, anger, ridicule, and humiliation." and the research conducted by Muhammad Adek (2017) "Black Campaign in the Presidential Election 2014 as the Discourse of Anti-Multiculturalism", by characteristic of attacking the subject with a distinctive lingual form of Indonesian Communist Party label as the enemy of the majority by an antimulticultural ideology".

\section{CONCLUSION AND SUGgESTION}

Based on the analysis of data and discussion, the forms of speech chosen based on the types of speech acts used, the spoken strategies applied, the application of the more dominant principles of politeness refers to the level facial vulnerability which is 'high enough', therefore, the level of politeness from Indonesian politicians used in the discourse of Jakarta elections is in 'less polite' category. 
The summary of this study indicates that politeness as a system of interpersonal relationships designed to facilitate interaction by minimizing the potential for conflict and confrontation, and politeness as a property agreed by speakers and addressee not to surpass their rights in communication, and politeness as an effort to create mutual trust and minimization the occurence of disrespectful statement are not considered and not obeyed by politicians in the discourse of Jakarta Election

From the findings of this study, in relation with the position of the politician as public figure, so there are some recommendations. Firstly, in order to speak politely, illocutionary force from the type of strong directive acts such as forcing and criticizing, it can be softened through alternative ways such as persuasion, prohibition, and salutation. Meanwhile, illocutionary force from the type of strong expressive acts such as criticism, threat and insulting can be softened through imperative offering and directing to interrogative construction. Secondly, political elites should give example to the public how to communicate well by establishing a tradition of polite language in politics and in goverment because language is the breath of communication based on the logic of truth so as capable to reflect the culture of civilized society, appreciate human differences, and preserve the unity of the nation.

\section{References}

Agustina and Syahrul R. "Portrait of politeness in language by the supporters of governor's candidates in the discourse of Jakarta election", Journal of Scientific Research and Studies, September 2017 volume 4 issue 9, pp, 237-244.

Adek, M. (2017). "Kampanye hitam dalam Pilpres 2014 sebagai wacana anti-multikulturalisme”, Prosiding Seminar Nasional Bahasa dan Sastra Indonesia dalam Gamitan Masyarakat Multikultural, . Padang: Sukabina.

Brown P. dan Levinson, S.C. (1987). Politeness: Some universals in language use. Cambridge, UK: Cambridge University Press. Blum-Kulka, S. (1987). "Indirectness and politeness in requests: same or different" Journal of Pragmatics 11.131-146.

Chaer A. dan Leoni A. (2010). Sosiolinguistik; sebuah pengantar. Jakarta: Rieneka Cipta.

Endraswara. (2011). Metodologi penelitian sastra: epistemologi, model, teori, dan aplikasi: Yogyakarta: CAPS.

Gunarwan A (1994). "Pragmatik: pandangan mata burung", in Dardjowidjojo (Editor) Mengiring rekan sejati: buat Pak Ton. Jakarta: Universitas Katolik Atmajaya.

Inayah W, Azyumardi A, I. Nugroho, "Perilaku elite: kekerasan verbal picu konflik sosial". Baranews.co (5/8/2017) Available: http://www. Baranews.co.

Leech, G. (1983). Principle of pragmatic. London: Longman.

Rahyono, F.X. "Kearifan dalam bahasa: sebuah tinjauan pragmatik terhadap profil kebahasaan media massa pascaorde baru" Jurnal Makara, Sosial, Humaniora, v ol. 9, no. 2, Desember 2015, pp 46-56.

Levinson, Stephen, C. (1983). Pragmatic. Cambridge: Cambridge University Press.

Moleong, Lexy J. (2010). Metode penelitian kualitatif: edisi revisi. Bandung: $\quad$ Remaja Rosdakarya.

Pranowo. (2009). Berbicara santun. Yogyakarta: Pustaka Pelajar.

Searle JR (1975). "Indirect speech act", in Cole, P \& Morgan, J.L. (ed.) Syntax and semantic Vol. 3: Speech acts. New York: Academic Press.

Semi M.A. (1993). Metode penelitian sastra. Bandung: Angkasa.

Sherry, H.Q., Agustina, dan Juita, N. (2012). Tindak tutur ilokusi dalam buku humor membongkar gurita Cikeas karya Jaim Wong Gendeng dan Implikasinya dalam pembelajaran Bahasa Idonesia. Jurnal Pendidikan Bahasa dan Sastra Indonesia, Universitas Negeri Padang, 1(1), pp 62-70.

Syahrul, R. (2008). Pragmatik kesantunan berbahasa: menyibak fenomena berbahasa Indonesia guru dan siswa. Padang: UNP Press.

Wijana IDP (1996). Dasar-dasar pragmatik. Yogyakarta: ANDI.

Yaolong, S. (2008). “A. Pragmatics study of politeness maxims in contemporary Chinese. International Forum of Teaching and Studies 4 (2), pp.27-59.

Yule G (2006). Pragmatics (Translation by Wahyuni, IP) Yogyakarta: Pustaka Pelajar. 